Article

\title{
Immobilization of Cellulase on a Functional Inorganic-Organic Hybrid Support: Stability and Kinetic Study
}

\author{
Jakub Zdarta *, Artur Jędrzak, Łukasz Klapiszewski and Teofil Jesionowski * \\ Institute of Chemical Technology and Engineering, Faculty of Chemical Technology, \\ Poznan University of Technology, Berdychowo 4, PL-60965 Poznan, Poland; artur.jedrzak@gmail.com (A.J.); \\ lukasz.klapiszeswki@put.poznan.pl (Ł.K.) \\ * Correspondence: jakub.zdarta@put.poznan.pl (J.Z.); teofil.jesionowski@put.poznan.pl (T.J.); \\ Tel.: +48-616-65-3747 (J.Z.); +48-616-65-3720 (T.J.)
}

Received: 7 November 2017; Accepted: 29 November 2017; Published: 1 December 2017

\begin{abstract}
Cellulase from Aspergillus niger was immobilized on a synthesized $\mathrm{TiO}_{2}$-lignin hybrid support. The enzyme was effectively deposited on the inorganic-organic hybrid matrix, mainly via physical interactions. The optimal initial immobilization parameters, selected for the highest relative activity, were $\mathrm{pH} 5.0,6 \mathrm{~h}$ process duration, and an enzyme solution concentration of $5 \mathrm{mg} / \mathrm{mL}$. Moreover, the effects of $\mathrm{pH}$, temperature, and number of consecutive catalytic cycles and the storage stability of free and immobilized cellulase were evaluated and compared. Thermal and chemical stability were significantly improved, while after $3 \mathrm{~h}$ at a temperature of $50{ }^{\circ} \mathrm{C}$ and $\mathrm{pH} 6.0$, the immobilized cellulase retained over $80 \%$ of its initial activity. In addition, the half-life of the immobilized cellulase ( $307 \mathrm{~min}$ ) was five times that of the free enzyme (63 min). After ten repeated catalytic cycles, the immobilized biocatalyst retained over $90 \%$ of its initial catalytic properties. This study presents a protocol for the production of highly stable and reusable biocatalytic systems for practical application in the hydrolysis of cellulose.
\end{abstract}

Keywords: enzyme immobilization; cellulases; titania-lignin hybrid; immobilized cellulase stability; cellulose hydrolysis

\section{Introduction}

Cellulases are classified as hydrolytic enzymes [1] and include at least three types of biocatalysts: endo-(1,4)- $\beta$-D-glucanase (EC 3.2.1.4), exo-(1,4)- $\beta$-D-glucanase (EC 3.2.1.91), and $\beta$-glucosidases (EC 3.2.1.21) [2-4]. They are produced by bacteria and microbes; however, the main enzyme acquisition process is based on fungi, which provide the highest production index $[1,5,6]$. The most frequently used for the production of cellulases are strains of cellulolytic fungi such as Aspergillus, Humicola, Penicillium, and Trichoderma $[7,8]$. Cellulases are responsible for the process of depolymerization of cellulose by delamination of the cell walls, which is a consequence of cellulose hydrolysis $[1,6]$. These biocatalysts have numerous practical applications in many fields of industry and agriculture. Commercial cellulases have been available for several decades, and have found applications in several important branches of industry, particularly in the wood and cellulose-paper industries, as well as in other branches including the conservation of thermoplastic polymers and plastics, bioconversion of cellulosic materials to organic solvents, fermentation processes, detergents, textiles, laundry, and the food and feed industries [9]. In view of the broad application of these enzymes, it is necessary to develop novel and more stable materials to enable the aforementioned processes to be carried out more efficiently.

Immobilization is a technique of confining cells or enzymes on organic, inorganic, or hybrid carriers [10]. Depending on the method of immobilization, the binding of the biocatalyst may occur 
more or less permanently. This technique is intended to increase the efficiency of catalytic processes, reduce the associated costs, and improve the properties of enzymes [10], mainly its stability at harsh reaction conditions, as variable reaction parameters might affect enzymes' properties. Among others, the most important properties are $\mathrm{pH}$ and temperature, as protein denaturation is caused mainly by abovementioned parameters [11]. Immobilization of enzymes enables the retention of catalytic activity, which results in the possibility of reusing the biocatalytic system. Moreover, easier and faster separation of immobilized enzymes from the reaction mixture makes them more attractive for industrial applications [11,12]. The immobilization of biocatalysts also prevents protein from entering the process in a mobile phase reactor containing the reagents, resulting in cleaner products [13].

As has already been noted, immobilization processes are of great importance and are used in many branches of industry, mainly in the pharmaceutical, food, chemical, and biological industries, but also in research and implementation of new technological solutions. The use of immobilized enzymes might result in greater process efficiency compared with the use of free biocatalysts, by better utilizing the potential of raw materials [11-14]. Various enzyme immobilization methods have enabled the development of industrial technology on a larger scale, reducing the costs of production. At present, there are several well-known techniques that rely on physical or chemical interactions $[11,14]$. Immobilized enzymes are a subject of great interest, which will certainly grow, as the properties of many of the biocatalysts are not yet fully known. Furthermore, the possibility of their immobilization may contribute to a steady progress in their development and use in bioprocesses and in the field of biosensing $[15,16]$.

The continuous development of technology helps obtain more effective and stable materials with targeted industrial applications. Nowadays, novel hybrid or composite material with immobilized enzymes, achieved by creating an innovative biocatalytic system, are increasingly used in many fields of industry, like pharmaceutical, chemical, and food industries. A combination of inorganic and organic components can provide advanced features such as better thermal and chemical resistance or electrokinetic and biological stability. For instance, Tao et al., used magnetic $\mathrm{Fe}_{3} \mathrm{O}_{4}-\mathrm{SiO}_{2}$ nanoparticles for the selective immobilization of cellulase [17]. The novel hybrid material, due to the influence of the metallic oxides, exhibited enhanced adsorption parameters as well as biocompatibility and bioactivity. Similar findings are reported by Velmurugan et al., who confirmed that a newly developed $\mathrm{MgO}-\mathrm{Fe}_{3} \mathrm{O}_{4}$ material was suitable for cellulose immobilization [18]. Furthermore, Hong et al., obtained a polyhedral oligomeric silsesquioxane-silica-titania $\left(\mathrm{POSS}-\mathrm{SiO}_{2}-\mathrm{TiO}_{2}\right.$ ) hybrid material for cellulase immobilization for biocatalytic applications [19]. In other studies laccase was successfully immobilized on $\mathrm{TiO}_{2}$ nanoparticles and $\mathrm{TiO}_{2}$ nanoparticle functionalized polyethersulfone (PES) membranes. The results revealed that both the immobilization procedures and the properties of the immobilization supports have significant impacts on the biocatalyst performance [20]. In addition, Hou et al. showed in [21] great potential for the application of the $\mathrm{TiO}_{2}$ based biocatalytic nanoparticles and membranes for $\mathrm{CO}_{2}$ conversion in a gas-liquid membrane contactor. These examples show that it is extremely important to continue research into the development of novel support materials for enzyme immobilization, which will lead to the creation of more effective and stable biocatalytic systems.

The main research goal of the present study was to evaluate a functional hybrid titanium dioxide-lignin hybrid material in terms of its suitability for the immobilization of cellulase, and to use the resulting biocatalytic system in the hydrolysis process of cellulose. The synthesized hybrid support was concisely characterized, immobilization of the enzyme was confirmed, and the effect of various operational conditions on the enzyme's stability and activity, as well as its reusability and storage stability, were examined. 


\section{Results}

\subsection{Synthesis of Titania-Lignin Hybrid Material and Cellulase Immobilization}

The thermal stability of the $\mathrm{TiO}_{2}$ modified by poly-L-lisine (PLL), lignin activated by sodium (meta)periodate and the synthesized $\mathrm{TiO}_{2}$-lignin hybrid material was determined using thermogravimetric analysis (TGA) (Figure 1). Commercial titanium dioxide after surface modification exhibited extremely high thermal stability, losing only about $2 \%$ of its mass in the analyzed temperature range, which might be explained by the evaporation of physically bound water. The thermogravimetric curve of the activated lignin showed a significant decrease in mass of the activated biopolymer consisted in three mass loss stages, at temperatures up to $200{ }^{\circ} \mathrm{C}$ (marked in yellow) and in the temperature ranges $200-600{ }^{\circ} \mathrm{C}$ (marked in blue) and $650-1000{ }^{\circ} \mathrm{C}$ (marked in red), linked respectively to the removal of physically bound water, decomposition of the lignin structure, and elimination of carbon and hydrogen atoms [22]. The synthesized $\mathrm{TiO}_{2}$-lignin hybrid showed relatively good thermal stability: up to a temperature of $1000{ }^{\circ} \mathrm{C}$ it lost about $10 \%$ of its mass. The high thermal stability (characteristic for $\mathrm{TiO}_{2}$ ) and the shape of the TGA curve for the obtained material, similar to that recorded for lignin, also proved the effective connection of $\mathrm{TiO}_{2}$ and lignin.

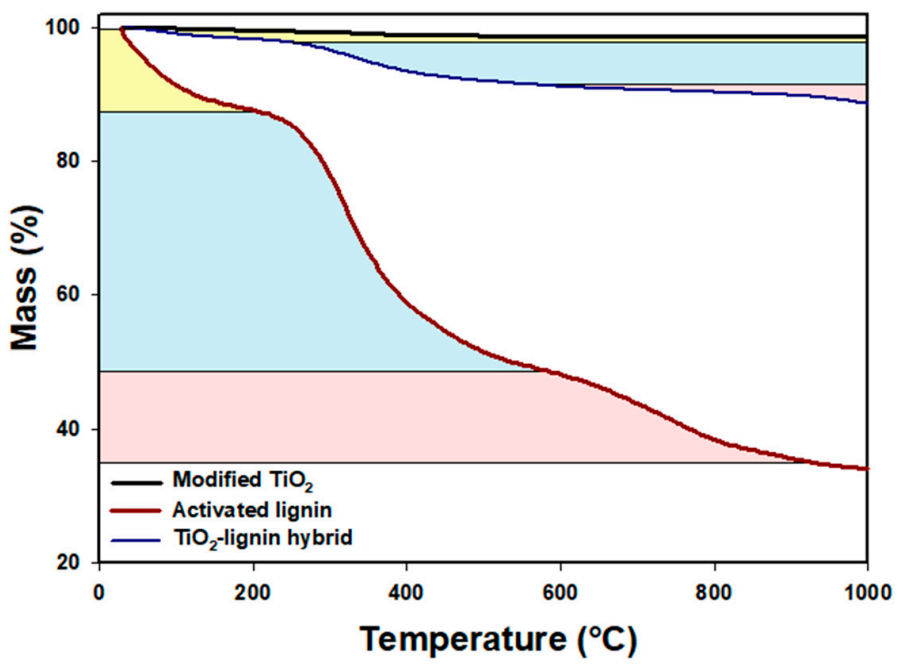

Figure 1. Results of thermogravimetric analysis of modified $\mathrm{TiO}_{2}$, activated lignin and $\mathrm{TiO}_{2}$-lignin hybrid.

The Fourier-transform infrared (FTIR) spectrum of the $\mathrm{TiO}_{2}$-lignin hybrid (Figure 2) contained many signals characteristic for functional groups of both modified precursors, which indirectly confirmed the effective synthesis of the hybrid support. Among these signals, the most important are those at wavenumbers $3450 \mathrm{~cm}^{-1}, 2940 \mathrm{~cm}^{-1}, 1680 \mathrm{~cm}^{-1}$, and around $1100 \mathrm{~cm}^{-1}$, attributed respectively to stretching vibrations of $-\mathrm{OH}$ groups, $\mathrm{C}-\mathrm{H}$ bonds, $\mathrm{C}=\mathrm{O}$ groups, and $\mathrm{C}-\mathrm{O}$ and $\mathrm{C}-\mathrm{O}-\mathrm{C}$ bonds in the lignin structure [23]. Signals were also observed in the wavenumber range 1600-1450 $\mathrm{cm}^{-1}$ and at $720 \mathrm{~cm}^{-1}$, representing, respectively, stretching vibrations of $C_{A r}-C_{A r}$ bonds in the structure of the biopolymer, and $\mathrm{Ti}-\mathrm{O}-\mathrm{Ti}$ bonds.

In the FTIR spectrum of free cellulase from Aspergillus niger, the most important signal is that at $3430 \mathrm{~cm}^{-1}$, characteristic for amine groups, which are mainly responsible for attachment of the enzyme to the solid support, as well as peaks around $1665 \mathrm{~cm}^{-1}$ and $1530 \mathrm{~cm}^{-1}$, generated by stretching vibrations of amide I and amide II bands. The FTIR spectrum of the produced biocatalytic system contains signals characteristic for cellulase as well as for the hybrid matrix. This suggested that the biocatalyst was successfully deposited on the surface of the support material. This is proven by the presence of a peak at $1090 \mathrm{~cm}^{-1}$ (C-N stretching vibrations) and changes in the intensity of signals generated by amine groups $\left(3430 \mathrm{~cm}^{-1}\right), \mathrm{C}-\mathrm{H}$ bonds $\left(2930 \mathrm{~cm}^{-1}\right)$, and amide bands, in comparison with the FTIR spectrum of the $\mathrm{TiO}_{2}$-lignin hybrid before enzyme binding. 


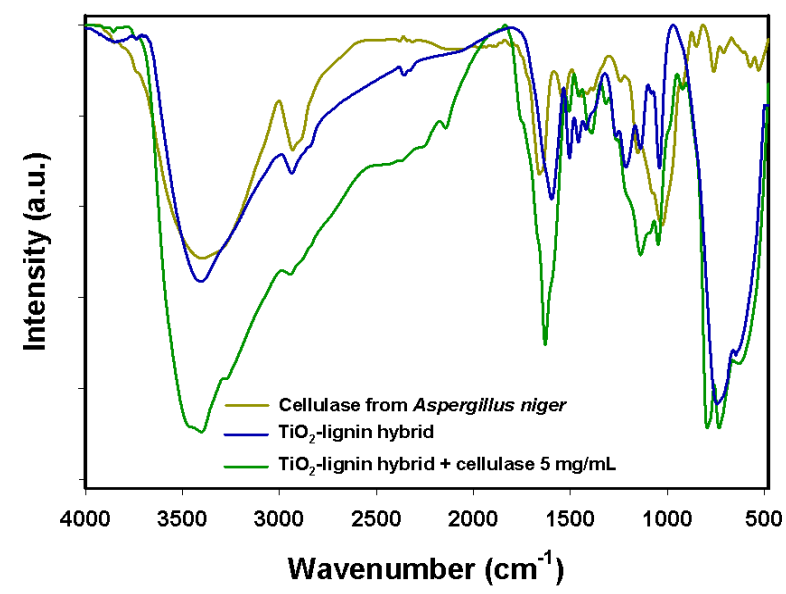

Figure 2. Results of Fourier-transform infrared (FTIR) analysis of cellulase from Aspergillus niger, $\mathrm{TiO}_{2}$-lignin hybrid and the product after enzyme immobilization (immobilization conditions: $\mathrm{pH}=7.0$, $T=4{ }^{\circ} \mathrm{C}, t=6 \mathrm{~h}, C_{\text {enz }}=5 \mathrm{mg} / \mathrm{mL}$ ).

Based also on the results of the analysis of the porous structure parameters of the $\mathrm{TiO}_{2}$-lignin support material before and after immobilization, some additional conclusions can be drawn. The synthesized $\mathrm{TiO}_{2}$-lignin hybrid before enzyme attachment had a relatively low surface area of around $10 \mathrm{~m}^{2} / \mathrm{g}$, while for the matrix after cellulase immobilization, this parameter decreased to about $8 \mathrm{~m}^{2} / \mathrm{g}$. This might suggest that effective enzyme attachment was achieved. Moreover, a decrease was recorded in the pores diameter and pores volume in the samples after immobilization. The hybrid biocomposite had pores with a mean diameter of $3.3 \mathrm{~nm}$ and a volume of $0.005 \mathrm{~cm}^{3} / \mathrm{g}$, while after cellulase immobilization these parameters fell to $1.7 \mathrm{~nm}$ and $0.003 \mathrm{~cm}^{3} / \mathrm{g}$.

\subsection{Cellulase Immobilization}

Besides confirmation of effective cellulase binding, the effect of initial immobilization parameters (process time and concentration of enzyme solution) on the quantity of immobilized enzyme and its relative activity was also evaluated (Figure 3).

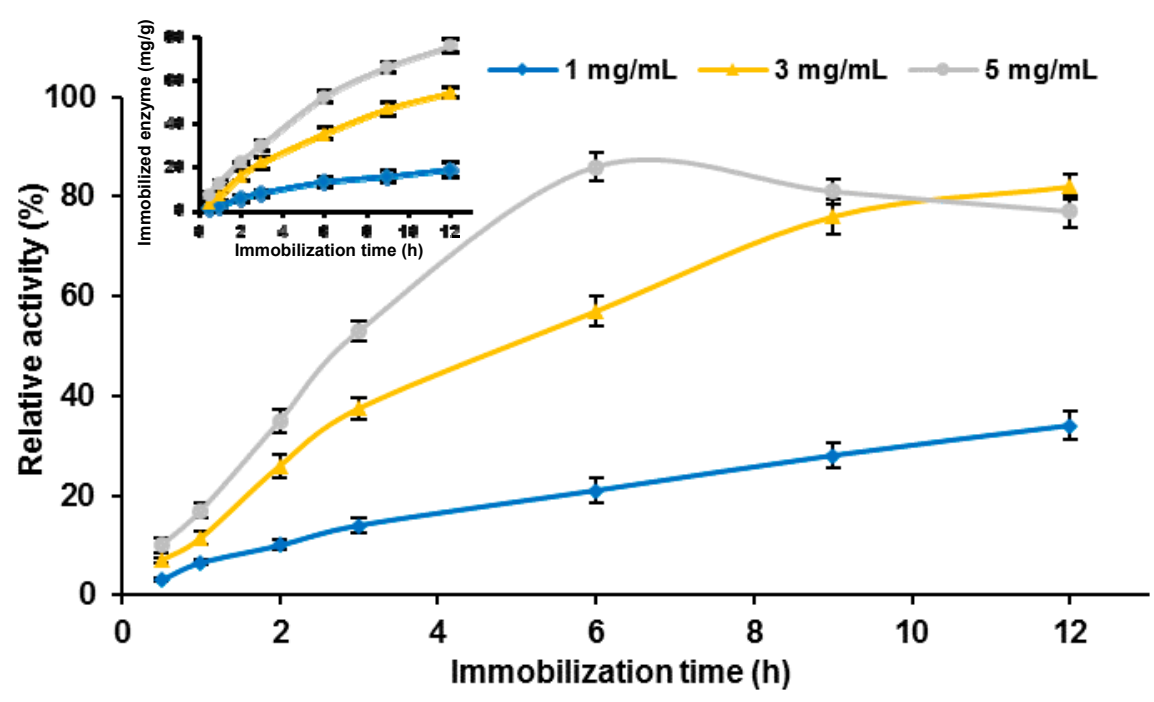

Figure 3. Effect of immobilization time on the relative activity of the immobilized cellulase. Inset: effect of immobilization time on the amount of the enzyme immobilized on the $\mathrm{TiO}_{2}$-lignin hybrid. 
As Figure 3 shows, the products after immobilization exhibited lower catalytic activity than free cellulase (relative activity up to $85 \%$ ). When solution concentrations of 1 and $3 \mathrm{mg} / \mathrm{mL}$ were used, the highest relative activities, of around 30\% and $80 \%$ respectively, were recorded after $12 \mathrm{~h}$ of the process. The amount of immobilized cellulase increased with process duration, irrespective of the concentration of the initial enzyme solution (Figure 3 inset). After $12 \mathrm{~h}$ of immobilization, 19, 55 , and $76 \mathrm{mg}$ of the biocatalyst per $1 \mathrm{~g}$ of the support material was deposited from solutions of 1 , 3 , and $5 \mathrm{mg} / \mathrm{mL}$ respectively. The results indicated that with increasing process time, the relative activity of the immobilized enzyme increased along with the amount of bounded cellulase, except in the case of the $5 \mathrm{mg} / \mathrm{mL}$ solution. When cellulase solution at this concentration was employed, the highest relative activity, about $85 \%$, was obtained after $6 \mathrm{~h}$ of immobilization. Further increase in the immobilization time caused the relative activity of the bound cellulase to decrease.

As has already been mentioned, the immobilization technique used led to the attachment of cellulase molecules mainly via physical and ionic interactions, but the formation of covalent bonds cannot be excluded. Electrokinetic measurements showed that the zeta potential of the titania-lignin hybrid matrix took negative values over the whole of the analyzed $\mathrm{pH}$ range, which indicates that the surface of the support material was negatively charged during immobilization. Under the immobilization conditions (acetate buffer at $\mathrm{pH} 4.8$ ), the enzyme molecules were positively charged (the IEP of cellulase is around 5). These facts imply that effective biocatalyst immobilization occurred mainly via electrostatic and ionic interactions. To verify this statement, solutions of sodium chloride at various ionic strengths were applied in cellulase desorption tests, because this salt might elute the enzyme by way of ionic exchange (Figure 4) [24].

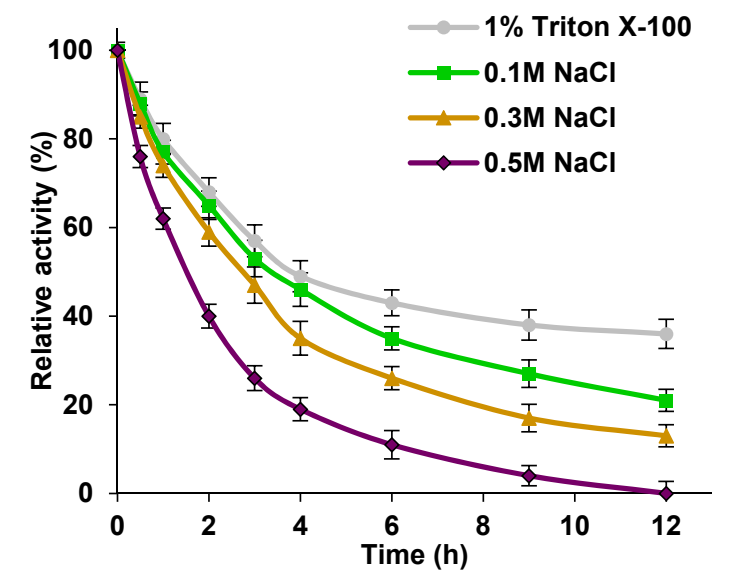

Figure 4. Effect of Triton $\mathrm{X}-100$ and $\mathrm{NaCl}$ solution on the relative activity of free and immobilized onto $\mathrm{TiO}_{2}$-lignin hybrid cellulase from Aspergillus niger.

Figure 4 shows that the relative activity of the immobilized cellulase treated with $1 \%$ Triton X-100 and $\mathrm{NaCl}$ solutions at various molar concentrations declined gradually during the first $6 \mathrm{~h}$ of treatment, which suggests elution of the enzyme from the matrix. The further decrease in relative activity is insignificant (less than $10 \%$ in all cases), which indicates that desorption occurred in the initial stages of the test and is limited in its later stages. After treatment with $1 \%$ Triton X-100 for $12 \mathrm{~h}$, the immobilized cellulase retained over $40 \%$ of its relative activity. When the immobilized biocatalyst was incubated in sodium chloride solutions at molarities of $0.1 ; 0.3$, and $0.5 \mathrm{M}$, a more significant drop in the relative activity was observed. The produced systems finally exhibited $25 \%, 18 \%$, and $0 \%$ of its relative activity, respectively. Additionally, to verify if the immobilized enzyme was eluted from the support material following the treatments or was deactivated by such treatments, amount of the immobilized enzyme retained on the matrix, after 6 and $12 \mathrm{~h}$ of desorption process was evaluated (Table 1). 
Table 1. Amount of the immobilized cellulase remained after desorption process, at different conditions.

\begin{tabular}{ccc}
\hline \multirow{2}{*}{ Type of Eluent } & \multicolumn{2}{c}{ Amount of Immobilized Enzyme (mg/g) } \\
\cline { 2 - 3 } & \multicolumn{2}{c}{ Desorption Time } \\
\cline { 2 - 3 } & $\mathbf{6} \mathbf{h}$ & $\mathbf{1 2} \mathbf{h}$ \\
\hline $1 \%$ Triton X-100 & $25.8 \pm 1.3$ & $22.4 \pm 1.6$ \\
$0.1 \mathrm{M} \mathrm{NaCl}$ & $20.3 \pm 1.5$ & $12.6 \pm 1.2$ \\
$0.3 \mathrm{M} \mathrm{NaCl}$ & $16.8 \pm 0.6$ & $6.9 \pm 0.9$ \\
$0.5 \mathrm{M} \mathrm{NaCl}$ & $9.7 \pm 1.0$ & $5.1 \pm 1.1$ \\
\hline
\end{tabular}

It can be seen from Table 2, that amount of the immobilized enzyme that remained on the surface of the hybrid material after desorption, irrespectively of the type and ionic strength of the eluent, is about $10-20 \%$ higher than amount of the immobilized cellulase, which corresponds to the evaluated relative activity of the biocatalytic system after desorption. The biggest differences were noticed for $0.5 \mathrm{M} \mathrm{NaCl}$ solution. After 6 and $12 \mathrm{~h}$ of the process, the surface of the titania-lignin hybrid retained 9.7 and $5.1 \mathrm{mg}$ of the enzyme per $1 \mathrm{~g}$ of the support. These values corresponded to the relative activity of $18.3 \%$ and $9.7 \%$, meanwhile, the noticed values of relative activity were $11.2 \%$ and $0 \%$.

\subsection{Stability Study of Immobilized Cellulase}

Various process parameters such as $\mathrm{pH}$ and temperature might affect the ability of the immobilized cellulase to degrade cellulosic material. Thus, in this study, the effect of the aforementioned parameters, as well as the chemical and thermal stability of the free and immobilized enzyme, were examined and compared. Moreover, the reusability and storage stability of the free and immobilized enzyme under different conditions were tested. Kinetic parameters for both forms of the enzyme were evaluated to verify how immobilization affected the affinity of the enzyme to the substrate molecules and its catalytic efficiency.

\subsubsection{Effect of $\mathrm{pH}$}

The effect of $\mathrm{pH}$ on the relative activity of free and immobilized cellulase was studied over a broad range of $\mathrm{pH}$ values, from 3.0 to 9.0 (Figure 5a).

The maximum relative activity was recorded at $\mathrm{pH} 5.5$ for the free enzyme, and at $\mathrm{pH} 6.0$ for the immobilized enzyme, as expected, since acidic cellulase was used in this study. Although the graph showed similar trends for the free and immobilized biocatalyst over the whole of the analyzed $\mathrm{pH}$ range, the immobilized biomolecules have higher relative activity than the free ones in the same $\mathrm{pH}$ conditions. The immobilized cellulase exhibited over $80 \%$ of its relative activity at $\mathrm{pH}$ values from 4.5 to 6.0 , as the free catalyst did so only at $\mathrm{pH}$ values from 5.0 to 6.0. The bound enzyme also exhibited about $20 \%$ higher relative activity $(76 \%)$ than the free enzyme (54\%) at $\mathrm{pH} 3.0$. The results also indicated a significant decrease in cellulase activity when the $\mathrm{pH}$ is above or below its optimum value. This was especially visible in alkaline conditions: at $\mathrm{pH}$ 9.0, both biocatalysts retained less than $40 \%$ of their activity. To test the chemical stability of the free and immobilized cellulase, both enzymes were incubated for $3 \mathrm{~h}$ under their optimal reaction conditions (Figure $5 \mathrm{~b}$ ). After $3 \mathrm{~h}$, the free cellulase retained about $20 \%$ of its initial activity, as the immobilized enzymes incubated at $\mathrm{pH} 5.0$ and 6.0 retained over $75 \%$ of their activity, which proved that cellulase attached to a $\mathrm{TiO}_{2}$-lignin hybrid support has higher thermal stability than the free enzyme. 
(a)

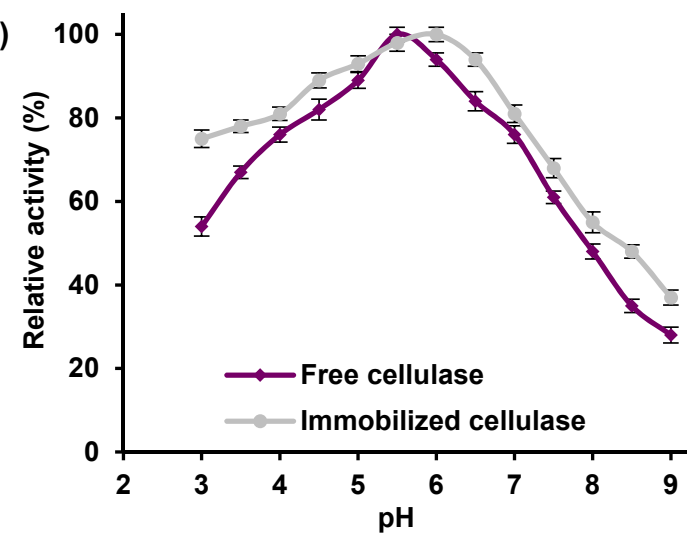

(b)

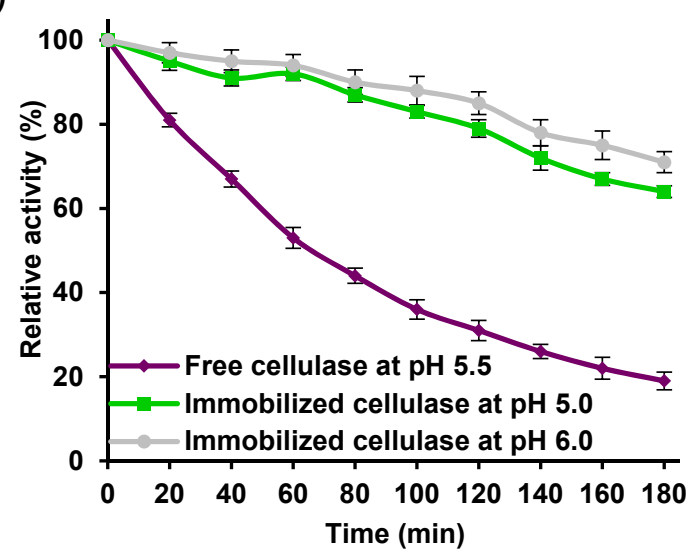

Figure 5. (a) Effect of $\mathrm{pH}$ on the relative activity of free and immobilized cellulose; (b) Chemical stability of free and immobilized enzyme after incubation for $3 \mathrm{~h}$ under optimal $\mathrm{pH}$ and temperature conditions.

\subsubsection{Effect of Temperature}

The effect of temperature on the relative activity of free and immobilized cellulase from Aspergillus niger was studied between 30 and $80{ }^{\circ} \mathrm{C}$, under optimal $\mathrm{pH}$ conditions for free and immobilized cellulase (Figure 6a).

The free enzyme exhibited its maximum activity at $50{ }^{\circ} \mathrm{C}$ and retained $80 \%$ of its activity in a temperature range from 45 to $60^{\circ} \mathrm{C}$. At temperatures below 50 and above $60^{\circ} \mathrm{C}$ the catalytic activity of the free biocatalyst significantly decreased, suggesting that the free enzyme is unstable in these conditions due to denaturation of the peptide structure [25]. By comparison, the immobilized cellulase exhibited its highest activity at temperatures of 55 and $60{ }^{\circ} \mathrm{C}$, and retained over $80 \%$ of its maximum activity over a wide temperature range from 40 to $70^{\circ} \mathrm{C}$. In addition, the drop in relative activity above $70{ }^{\circ} \mathrm{C}$ is less significant that in the case of the free enzyme, while at $80^{\circ} \mathrm{C}$ the bound cellulase exhibited over $60 \%$ of its relative activity. To determine the thermal stability of the immobilized cellulase, the free enzyme was incubated for $3 \mathrm{~h}$ at $50{ }^{\circ} \mathrm{C}$ and the immobilized cellulase at 50 and $60{ }^{\circ} \mathrm{C}$ (Figure $6 \mathrm{~b}$ ). After $3 \mathrm{~h}$, the relative activity of the immobilized cellulase remained at a high level (over $75 \%$ and $80 \%$, at temperatures of 50 and $60{ }^{\circ} \mathrm{C}$, respectively). Meanwhile, there was more significant decline in the catalytic properties of the free enzyme, which after $3 \mathrm{~h}$ of incubation had lost almost $80 \%$ of its activity. 
(a)

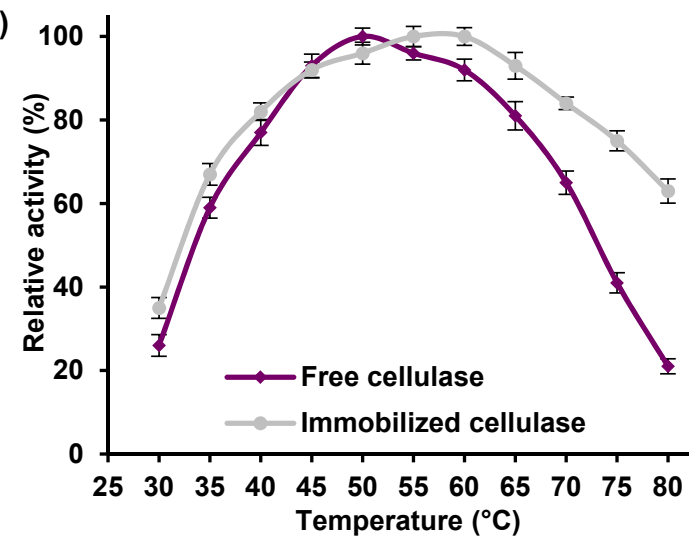

(b)

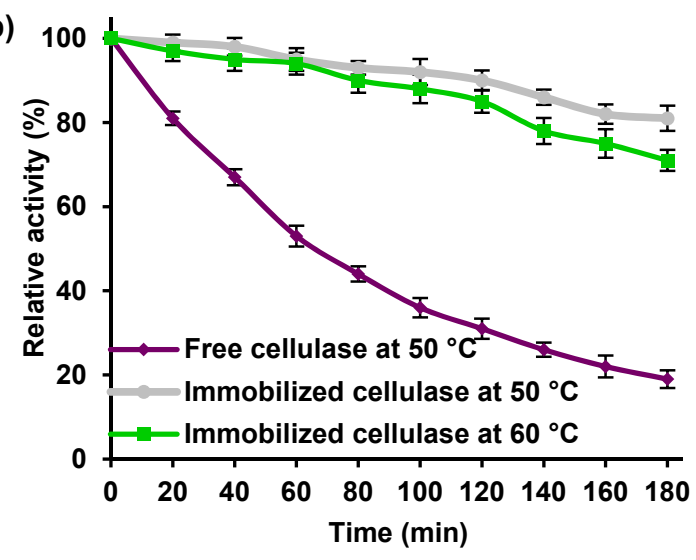

Figure 6. (a) Effect of temperature on the relative activity of free and immobilized cellulose; (b) Thermal stability of free and immobilized enzyme after incubation for $3 \mathrm{~h}$ under optimal temperature and pH conditions.

\subsubsection{Storage Stability and Reusability}

The storage stability of free and immobilized cellulase at 4 and $25{ }^{\circ} \mathrm{C}$ was evaluated by measuring the enzyme's relative activity every 5 days for 30 days (Figure 7a).

It can be seen that, irrespective of the storage temperature, the immobilized enzyme was characterized by higher activity than the free cellulase: after 30 days of storage at 4 and $25{ }^{\circ} \mathrm{C}$, it retained over $95 \%$ and $85 \%$ of its initial activity, compared with less than $75 \%$ and less than $40 \%$ in the case of the free enzyme. These results indicated that the immobilization strategy used in this study improved the storage stability of the cellulase.

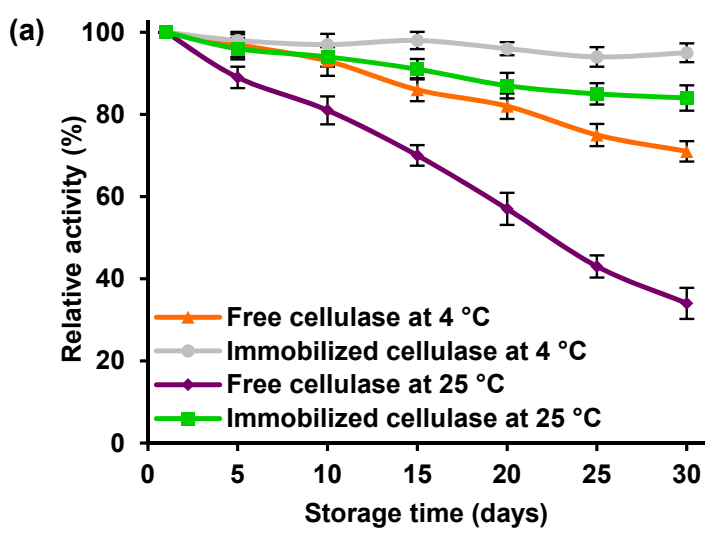

Figure 7. Cont. 
(b)

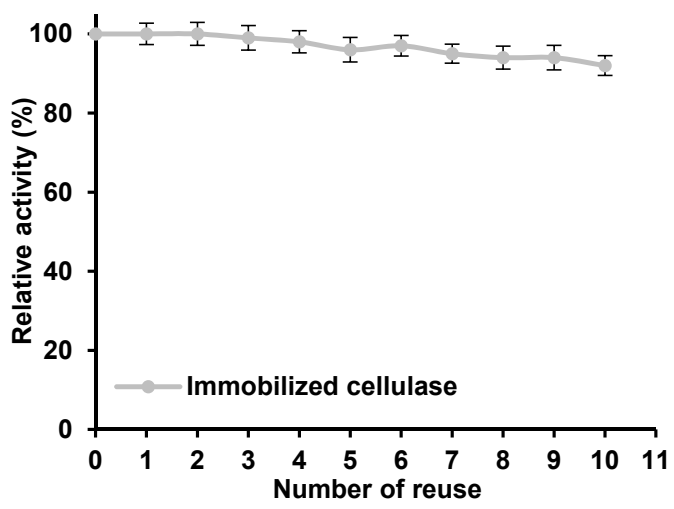

Figure 7. (a) Relative activity of free and immobilized cellulase stored for 30 days at $4{ }^{\circ} \mathrm{C}$ and $25{ }^{\circ} \mathrm{C}$;

(b) Reusability of the immobilized cellulase.

In this study, reusability of the bounded enzyme was evaluated over ten consecutive cycles of cellulose hydrolysis (Figure $7 \mathrm{~b}$ ). As can be seen, the relative activity of the immobilized cellulase remained almost unaltered during repeated catalytic cycles, and after ten cycles it retained $93 \%$ of its initial activity.

\subsection{Kinetic Parameters of Free and Immobilized Cellulase}

It is clear that, with changes in the three-dimensional structure of the enzyme, and its $\mathrm{pH}$ and temperature profiles as a result of immobilization, its kinetic parameters might also be affected. Kinetic parameters, including $K_{\mathrm{m}}, V_{\max }$, and turnover number $\left(k_{\text {cat }}\right)$, were determined for both free and immobilized cellulase by measuring the initial reaction rates during the hydrolysis of cellulose with various initial concentrations of substrate, under optimal process conditions (Table 2).

Table 2. Kinetic parameters of cellulase from Aspergillus niger, free and immobilized on $\mathrm{TiO}_{2}$-lignin hybrid.

\begin{tabular}{ccc}
\hline Kinetic Parameters & Free Cellulase & Immobilized Cellulase \\
\hline$K_{\mathrm{m}}(\mathrm{mM})$ & $2.06 \pm 0.85$ & $2.63 \pm 0.96$ \\
$V_{\max }(\mathrm{U} / \mathrm{mg})$ & $159 \pm 11$ & $125 \pm 19$ \\
$k_{\mathrm{cat}}\left(\mathrm{s}^{-1}\right)$ & $145 \pm 19$ & $114 \pm 15$ \\
$k_{\mathrm{cat}} / K_{\mathrm{m}}\left(\mathrm{s}^{-1} \cdot \mathrm{mM}^{-1}\right)$ & $70.5 \pm 3.5$ & $43.6 \pm 3.2$ \\
$t_{1 / 2}(\mathrm{~min})$ & $63 \pm 13$ & $307 \pm 21$ \\
\hline
\end{tabular}

It can be seen that for the immobilized cellulase the value of $K_{\mathrm{m}}$ reached $2.63 \mathrm{mM}$, which is higher in comparison with free enzyme $(2.06 \mathrm{mM})$, while the $V_{\max }$ value recorded for the immobilized enzyme (159 U/mg) was lower than for free cellulase. Nevertheless, higher values of the Michaelis-Menten constant and lower values of $V_{\max }$ after immobilization are typical for immobilized biocatalysts. A similar pattern was observed for turnover number $\left(k_{\text {cat }}\right)$, which after immobilization took a value of $114 \mathrm{~s}^{-1}$, and is lower than noticed for the free enzyme $\left(145 \mathrm{~s}^{-1}\right)$. In consequence, the value of catalytic efficiency $\left(k_{\text {cat }} / K_{\mathrm{m}}\right)$ recorded for the immobilized cellulase $\left(43.6 \mathrm{~s}^{-1} \cdot \mathrm{mM}^{-1}\right)$ is also significantly lower than that of the free biocatalyst $\left(70.5 \mathrm{~s}^{-1} \cdot \mathrm{mM}^{-1}\right)$. This can be explained by the decrease in the affinity of the immobilized biomolecules to the substrate molecules. Nevertheless, it should be emphasized that the half-life $\left(t_{1 / 2}\right)$ calculated for the immobilized cellulase $(307 \mathrm{~min})$ is almost five times as long as that of the free enzyme $(63 \mathrm{~min})$. 


\section{Discussion}

\subsection{Synthesis of Titania-Lignin Hybrid Material and Cellulase Immobilization}

The synthesized $\mathrm{TiO}_{2}$-lignin hybrid support was found to have relatively high thermal stability, significantly higher than that of activated kraft lignin. The improvement in thermal stability was a direct result of the incorporation of titanium dioxide particles, known to be highly thermo-resistant, into the hybrid material. The presence of various chemical moieties, such as $-\mathrm{OH}, \mathrm{C}=\mathrm{O}$, and $\mathrm{C}-\mathrm{O}$, in the structure of the synthesized material facilitated the attachment of the cellulase molecules and the formation of relatively stable interactions. From the FTIR spectrum of the free enzyme, it can be concluded that the biocatalyst was attached mainly through the amine groups $\left(-\mathrm{NH}_{2}\right)$ present in its structure. However, particular attention should be paid to the shifts in the signals attributed to amide I bands from $1665 \mathrm{~cm}^{-1}$ (free enzyme) to $1645 \mathrm{~cm}^{-1}$ (immobilized cellulase), which suggests a mixed mechanism of interaction based mainly on the formation of physical and ionic interactions as well as covalent bonds between the enzyme and support [26]. By contrast, Tao et al. used a magnetite-silica hybrid support modified by arginine for the immobilization of cellulase. They observed that at $\mathrm{pH}$ above 5.0, the enzyme is negatively charged while arginine is positively charged, and in consequence, the formation of electrostatic interactions was strongly favored [17]. Moreover, after immobilization, the values of BET (Brunauer-Emmett-Teller) surface area, mean pores size, and pores volume were reduced, which suggests that the enzyme particles may be immobilized in the pores of the support as well as on its surface [27].

\subsection{Cellulase Immobilization}

During the study, it was also investigated how the catalytic activity of the immobilized enzyme depends on the initial immobilization parameters, namely the concentration of enzyme solution and immobilization time. The best catalytic properties were recorded for the system obtained after $6 \mathrm{~h}$ of immobilization from a cellulase solution with a concentration of $5 \mathrm{mg} / \mathrm{mL}$, even though a greater amount of the enzyme was immobilized after a longer process time. This fact might be explained by the overloading of enzyme particles on the surface of the hybrid support, causing steric hindrances and diffusional limitations in transport of the reaction mixture components to the active sites of the enzyme [28]. In consequence, the relative activity of the immobilized enzyme decreased. Thus, the above parameter values were determined as the optimal immobilization conditions.

To confirm the type of interactions formed between the cellulase and hybrid support, solutions of Triton X-100 and sodium chloride at various concentrations were used to determine their effect on the activity of the immobilized enzyme. A significant decrease in relative activity might suggest that the cellulase is linked to the hybrid support mainly via hydrogen bonds and ionic interactions. The formation of these types of interactions is related to the presence of negative and positive charges on the surface of the matrix and in the structure of the enzyme, respectively in the conditions of the immobilization process. However, such interactions are unstable under the conditions of the desorption tests. In fact, the immobilized enzyme retained its catalytic properties, which indicates that covalent bonds are also present between the biomolecules and support material [29]. This is confirmed by the findings of Hirsh et al., who used polystyrene film after surface activation by plasma immersion ion implantation. They reported that, when cellulase was immobilized via covalent bonds, desorption was strongly reduced and the enzyme retained its catalytic properties [30]. Moreover, changes in the relative activity of immobilized cellulase after treatment with $\mathrm{NaCl}$ solutions at various concentrations indicated that the ionic strength of the solutions affected the catalytic activity of the immobilized cellulase. It also should be added that this statement is confirmed by the results of the immobilized enzyme retained on the surface of the support after desorption, which is higher than the amount of the enzyme corresponding to the measured relative activity. This could suggest that the enzyme is not only desorbed by the eluent, but partially might be also deactivated by the treatment, which is particularly noticeable in the presence of $0.5 \mathrm{M} \mathrm{NaCl}$. 


\subsection{Stability Study of Immobilized Cellulase}

During the immobilization process, the structure of biocatalysts may be altered, causing changes in their activity and stability. It has been shown that immobilized cellulase exhibited higher stability than the free enzyme over the analyzed $\mathrm{pH}$ range; however, the catalytic properties are significantly better in acidic than in alkaline conditions. This might be explained by the fact that in a basic environment, ionic groups present in the cellulase molecules form an electrostatic repulsion which influences the three-dimensional structure of the enzyme, leading to disruption and destruction of the active sites of the cellulase, and thus impairing its catalytic properties [31]. Similar observations were reported by Khorshidi et al., who cross-linked cellulase aggregates on amine-functionalized $\mathrm{Fe}_{3} \mathrm{O}_{4}$-silica core-shell magnetic nanoparticles. They recorded a large decrease in the enzyme's catalytic properties at $\mathrm{pH}$ values above 5.0 [32]. By comparison, in this study, the relative activity of immobilized cellulase measured at $\mathrm{pH} 7.0$ was around $80 \%$, proving that application of the titania-lignin hybrid as a support significantly improved the $\mathrm{pH}$ resistance of the cellulase. This may be explained by the protective effect of the hybrid support against conformational changes caused by harsh $\mathrm{pH}$ conditions [33] and by the fact that after immobilization, interactions between the biocatalyst and carrier are formed which stabilize the entire structure of the enzyme [34]. Results relate to the thermal stability clearly show that the stability of the cellulase was improved after immobilization on the $\mathrm{TiO}_{2}$-lignin hybrid. This was probably because the immobilization process provided an additional external backbone and stabilization for the molecules of cellulase, as a result of the formation of interactions between the enzyme and support [35]. Moreover, as an effect of immobilization, thermal vibrations of cellulase biomolecules were reduced, which limited conformational changes caused by heat and helped to maintain the proper globular structure of the entire biomolecule [36,37]. Similar findings to those presented in this study were reported by Sanchez-Ramirez et al., who used another inorganic-organic hybrid support (chitosan-coated magnetic nanoparticles) for covalent immobilization of Trichoderma reesei cellulase, and found that the resulting biocatalytic system exhibited its maximum activity at $60^{\circ} \mathrm{C}$. In addition, after $3 \mathrm{~h}$ of incubation at that temperature, it retained about $60 \%$ of its initial activity; however, an increase in the temperature by $10{ }^{\circ} \mathrm{C}$ caused the relative activity to drop significantly, to below $40 \%$ [38]. By contrast, cellulase immobilized on the titania-lignin support retained over $80 \%$ of its activity after $3 \mathrm{~h}$ of incubation at $70{ }^{\circ} \mathrm{C}$.

The storage stability of cellulase from Aspergillus niger was found to be significantly improved following immobilization. This can probably be attributed to a reduction in the dissociation of peptide subunits and in the enzyme denaturation rate [39]. A significant increase in the storage stability of immobilized cellulase was also reported when graphene oxide supplemented by magnesium oxide nanoparticles was used as a support. In that study, after 30 days of storage the free enzyme retained less than $20 \%$ of its initial catalytic activity, compared with over $80 \%$ for the immobilized biocatalyst [40]. It was also found that the immobilized cellulase can be used in as many as ten reaction cycles without significant loss of activity. The observed slight decrease in catalytic properties is probably related to the relatively weak strength of the interactions (mainly ionic interactions and van der Waals forces) between the enzyme and support, which causes partial leakage of the catalyst from the support. Moreover, the immobilized cellulase may undergo partial inactivation as a result of its repeated use [41]. Nevertheless, the results clearly show that immobilization is an effective tool to ensure the reusability of cellulase in the hydrolysis of cellulose. Earlier studies of cellulase immobilization have reported the retention of about $40 \%$ and $70 \%$ of initial activity after eight biocatalytic cycles, when the enzyme was attached to, respectively, magnetic nanoparticles consisting of hematite and ferrite activated by glutaraldehyde, and magnetic nanoparticles encapsulated in polymer nanospheres [34,42]. Such improvement in the operational stability and reusability of cellulase makes it more suitable for large-scale processes and greatly increases its economic viability. 


\subsection{Kinetic Parameters of Free and Immobilized Cellulase}

The observed increase in the value of $K_{\mathrm{m}}$ and simultaneous decrease in $V_{\max }$ reflect a lower affinity to the substrate, and consequently a lower maximum reaction rate, in the case of the immobilized enzyme. These changes are probably related to the creation of diffusional limitations and changes in the structure of the enzyme caused by its attachment to the solid support, which blocks active sites of the enzyme and restricts transport of the substrates [43]. In addition, the decrease in the turnover number after immobilization suggests that the binding process has a negative effect on substrate conversion by the immobilized cellulase. However, a significant (fivefold) increase in the enzyme's half-life was recorded, indicating that cellulase attached to the $\mathrm{TiO}_{2}$-lignin hybrid support retains its catalytic properties for a longer time than the free enzyme. These findings are in agreement with the data on thermal and chemical stability, which show a significant improvement in the stability of the cellulase after immobilization. The foregoing observations are in agreement with data published by Senyay-Oncel and Yesil-Celiktas, which showed that after the immobilization of cellulase on commercially available $\mathrm{NaY}$ zeolite, its substrate affinity and reaction rate also decreased [44]. Nonetheless, their study found much more significant changes in $K_{\mathrm{m}}$ (a 100\% rise), $V_{\max }$ (a 30\% drop), and $k_{\text {cat }}$ (a $50 \%$ drop) than in the present study.

\section{Materials and Methods}

\subsection{Materials}

Cellulase from Aspergillus niger (EC 3.2.1.4, product number 22178), poly-L-lisine (PLL), kraft lignin, sodium (meta)periodate, cellulose, glucose, Whatman ${ }^{\circledR}$ qualitative filter paper (Grade 1 circles, diam. $15 \mathrm{~mm}$ ), 3,5-dinitrosalicylic acid (3,5-DNS), sodium chloride, Triton X-100, phosphate buffer (PBS) at pH 7, acetate buffer at pH 4.8, Coomassie Brilliant Blue G-250 (CBB G-250), and bovine serum albumin (BSA) were delivered by Sigma-Aldrich (St. Louis, MO, USA). Commercially available titanium dioxide (product name Tytanpol ${ }^{\circledR}$ R-001) was supplied by Grupa Azoty SA (Tarnów, Poland). Sodium hydroxide, hydrochloric acid, dioxane, 96\% ethyl alcohol, and 85\% phosphoric acid were delivered by Chempur (Katowice, Poland).

\subsection{Synthesis of $\mathrm{TiO}_{2}-$ Lignin Hybrid Support Material}

The synthesis of a titania-lignin hybrid support was carried out in three steps, using the method described in our previous work $[45,46]$ with some modifications. In this study, the titanium dioxide was modified with poly-L-lysine (PLL), in view of its peptide nature and to increase the amount of reactive chemical groups for the effective binding of lignin. For surface functionalization of $\mathrm{TiO}_{2}$, it was suspended in PBS at pH 7, then a $10 \%(\mathrm{w} / \mathrm{w})$ solution of PLL was added. The mixture was shaken for $12 \mathrm{~h}$ (KS260 Basic, IKA Werke GmbH, Staufen im Breisgau, Germany) at $4{ }^{\circ} \mathrm{C}$ and centrifuged (Eppendorf Centrifuge 5810 R, Hamburg, Germany), and washed with deionized water to remove unbound PLL and PBS. In the next step, kraft lignin was activated by sodium (meta)periodate. Finally, the activated lignin and modified titanium dioxide were linked at a mass ratio of 1:1.

\subsection{Immobilization of Cellulase from Aspergillus niger}

Immobilization was carried out using $0.25 \mathrm{~g}$ of the previously obtained $\mathrm{TiO}_{2}$-lignin hybrid support, to which $10 \mathrm{~mL}$ of a solution of cellulase from Aspergillus niger, at concentrations of 1.0, 3.0 , and $5.0 \mathrm{mg} / \mathrm{mL}$ in acetate buffer at $\mathrm{pH} 4.8$, was added. The mixture was shaken for a specified period of time $(1,2,3,6,9$, or $12 \mathrm{~h}$ ) in a KS 4000i Control incubator (IKA Werke GmbH, Staufen im Breisgau, Germany) at a temperature of $4{ }^{\circ} \mathrm{C}$. Finally, the products were centrifuged (Eppendorf Centrifuge 5810 R, Hamburg, Germany) and washed several times with the acetate buffer to remove unbound enzyme. 


\subsection{Characterization of the Hybrid Support and Product after Immobilization}

Thermogravimetric curves for the modified $\mathrm{TiO}_{2}$, activated lignin, and synthesized $\mathrm{TiO}_{2}-$ lignin hybrid material (sample weight approximately $10 \mathrm{mg}$ ) were obtained using a Jupiter STA449F3 apparatus (Netzsch, Selb, Germany). Measurements were made at a heating rate of $10{ }^{\circ} \mathrm{C} / \mathrm{min}$ over the temperature range $25-1000{ }^{\circ} \mathrm{C}$ under nitrogen flow $(10 \mathrm{~mL} / \mathrm{min})$.

Porous structure parameters (BET surface area, pores diameter and pores volume) were determined using an ASAP 2020 instrument (Micromeritics Instrument Co., Norcross, GA, USA). The surface area was evaluated based on the multipoint BET (Brunauer-Emmett-Teller) method using data for nitrogen adsorption under relative pressure $\left(p / p_{0}\right)$. The $\mathrm{BJH}$ (Barrett-Joyner-Halenda) algorithm was applied to examine the mean size and total volume of pores.

Zeta potential measurements were made on a Zetasizer Nano ZS instrument (Malvern Instruments Ltd., Malvern, UK) equipped with an autotitrator. The measurements were performed in a $0.001 \mathrm{M} \mathrm{NaCl}$ solution over the $\mathrm{pH}$ range 2.0-11.0. The zeta potential was computed using Henry's equation.

Fourier transform infrared (FTIR) spectra were obtained using a Vertex 70 spectrophotometer (Bruker, Billerica, MA, USA), analyzing samples in the form of $\mathrm{KBr}$ pellets at a resolution of $0.1 \mathrm{~cm}^{-1}$ over a wavenumber range of $4000-400 \mathrm{~cm}^{-1}$. Pellets were made by mixing $200 \mathrm{mg}$ of anhydrous potassium bromide and $2 \mathrm{mg}$ of the sample.

The amount of cellulase immobilized on the hybrid support was evaluated based on the Bradford method [47]. Briefly, amount of the cellulase was measured before and after immobilization at wavelength $595 \mathrm{~nm}$, using a calibration curve based on BSA solutions at known concentrations to calculate the quantity of immobilized enzyme present, in mg of cellulase per gram of support.

\subsection{Activity and Stability of Free and Immobilized Cellulase}

The catalytic activity of free and immobilized cellulase was evaluated by measuring the quantity of reducing sugars (glucose) during hydrolysis of the cellulose substrate. The concentration of glucose was quantified using the previously described DNS method [48]. The activity measurements were carried out as follows: $50 \mathrm{mg}$ of cellulosic substrate (Whatman ${ }^{\circledR}$ paper) was placed in acetate buffer at $\mathrm{pH} 4.8$, and $10 \mathrm{mg}$ of free or immobilized cellulase was added to the reactor. The mixture was incubated for $60 \mathrm{~min}$ at $50^{\circ} \mathrm{C}$. The reaction was terminated by the addition of $2 \mathrm{~mL}$ of 3,5-DNS. The resulting solution was then incubated at $100{ }^{\circ} \mathrm{C}$ for $5 \mathrm{~min}$ in an oil bath, and after that time was immediately cooled in ice. Samples were then diluted with distilled water and centrifuged (Eppendorf Centrifuge $5810 \mathrm{R}$, Hamburg, Germany) to remove solid particles, and were subjected to spectrophotometric measurements at $540 \mathrm{~nm}$ using a Jasco V-750 UV-Vis spectrophotometer (Jasco, Tokyo, Japan). The calibration curve of glucose was used to determine the relation between absorbance and the quantity of reducing sugars. All measurements were made in triplicate. One enzyme activity unit (U) of free and immobilized cellulase was defined as the amount of enzyme that produced $1 \mu \mathrm{mol}$ of glucose per minute.

The relative activity $\left(A_{\mathrm{R}}\right)$ (Equation (1)) was defined as the percentage ratio of the activity of cellulase at a specific value $\left(A_{\mathrm{i}}\right)$ to the enzyme's maximum activity $\left(A_{\max }\right) . A_{\max }$ is the highest activity among all values of enzymatic activity recorded in this study.

$$
A_{\mathrm{R}}=\frac{A_{\mathrm{i}}}{A_{\max }} \times 100 \%
$$

Also based on the above-mentioned reaction, the effect of $\mathrm{pH}$ and temperature on the activity of immobilized cellulase, as well as its thermal and chemical stability, storage stability, and reusability, were evaluated. The effect of $\mathrm{pH}$ was studied by incubating the reaction mixture with free or immobilized cellulase at $\mathrm{pH}$ values ranging from 3 to 9 ( $\mathrm{pH}$ was adjusted by the addition of $0.1 \mathrm{M} \mathrm{HCl}$ or $\mathrm{NaOH}$ ). The effect of temperature was evaluated over the temperature range $30-80{ }^{\circ} \mathrm{C}$ by incubating the reaction mixture under the desired temperature conditions. $\mathrm{pH}$ and thermal inactivation curves for free cellulase were examined after incubation of the free enzyme at $\mathrm{pH} 5.5$ and a temperature 
of $50{ }^{\circ} \mathrm{C}$ for $3 \mathrm{~h}$. Thermal inactivation curves of immobilized cellulase were evaluated after $3 \mathrm{~h}$ of incubation at $\mathrm{pH} 6$ at temperatures of 50 and $60^{\circ} \mathrm{C}$, while $\mathrm{pH}$ inactivation curves were examined after $3 \mathrm{~h}$ of incubation at $60^{\circ} \mathrm{C}$, at pH 5 and 6 . The reusability of the immobilized cellulase was examined by measuring enzymatic activity in ten consecutive reaction cycles. After each hydrolysis cycle, the immobilized cellulase was separated from the reaction mixture by centrifugation and washed with buffer solution before the next cycle. The enzymatic activity in the first cycle was defined as $100 \%$, and relative activity was calculated for the following cycles. Storage stability was evaluated every 5 days under optimum reaction conditions for free and immobilized cellulase stored at 4 and $25^{\circ} \mathrm{C}$, in phosphate buffer at $\mathrm{pH} 7$. The initial activity was defined as $100 \%$.

The effect of $1 \%$ Triton X-100 and sodium chloride solutions at various concentrations $(0.1-0.5 \mathrm{M})$ on the relative activity of immobilized cellulase from Aspergillus niger was evaluated over a time of $12 \mathrm{~h}$. For this purpose, the immobilized enzyme was dispersed in sodium chloride or Triton X-100 solution. After the specified period of time, the relative activity of the immobilized enzyme was evaluated based on the hydrolysis reaction of the cellulosic substrate.

\subsection{Kinetic Parameters of Free and Immobilized Enzyme}

The Lineweaver-Burk plots were used to evaluate the kinetic parameters: the Michaelis-Menten constant $\left(K_{\mathrm{m}}\right)$, maximum reaction rate $\left(V_{\max }\right)$, specificity constant $\left(k_{\mathrm{cat}} / K_{\mathrm{m}}\right)$, and turnover number $\left(k_{\text {cat }}\right)$ of free and immobilized cellulase. These parameters were evaluated based on the hydrolysis reaction of cellulose substrate at different concentrations. Initial reaction rates were evaluated under optimum reaction conditions.

\section{Conclusions}

The results presented in this study clearly demonstrate that cellulase, an industrially relevant enzyme, was successfully immobilized on a hybrid $\mathrm{TiO}_{2}$-lignin support material. The immobilized cellulase exhibited significant improvement in thermal and chemical stability (with relative activity above $80 \%$ after $3 \mathrm{~h}$ of incubation). Furthermore, after 10 consecutive hydrolysis cycles the immobilized cellulase retained over $90 \%$ of its initial activity, which confirms its operational stability, a relevant feature for industrial applications. The approach described here provides an efficient and simple method for the synthesis of a hybrid titanium dioxide-lignin material and its application as a support material for the immobilization of cellulase. The produced biocatalytic system may be employed in industrial applications without significant loss of its properties over several cycles. Moreover, the synthesized hybrid material and the applied immobilization methodology might easily be used for the immobilization of other biocatalysts.

Acknowledgments: The scientific work was financed from budgetary resources for science in the years 2016-2019, project number IP2015 032574 (Iuventus Plus).

Author Contributions: J.Z. planned the studies, evaluated the enzyme immobilization efficiency and the immobilized enzyme's activity and stability, as well as developed results. A.J. prepared the functional hybrid material and carried out the immobilization experiments. Ł.K. interpreted the data and wrote up the results. T.J. coordinated all project tasks, planned the studies, developed the results, and participated in discussions.

Conflicts of Interest: The authors declare no conflict of interest. The funding sponsors had no role in the design of the study; in the collection, analysis, or interpretation of data; in the writing of the manuscript; or in the decision to publish the results.

\section{References}

1. Gupta, C.; Jain, P.; Kumar, D.; Dixit, A.K.; Jain, R.K. Production of cellulase enzyme from isolated fungus and its application as efficient refining aid for production of security paper. Int. J. Appl. Microbiol. Biotechnol. Res. 2015, 3, 11-19.

2. Zhang, Y.H.P.; Himmel, M.E.; Mielenz, J.R. Outlook for cellulase improvement: Screening and selection strategies. Biotechnol. Adv. 2006, 24, 452-481. [CrossRef] [PubMed] 
3. Kuhad, R.C.; Singh, A.; Eriksson, K.E. Microorganisms and enzymes involved in the degradation of plant fiber cell walls. Adv. Biochem. Eng. Biotechnol. 1997, 57, 45-125. [PubMed]

4. Deswal, D.; Khasa, Y.P.; Kuhad, R.C. Optimization of cellulase production by a brown rot fungus Fomitopsis sp. Bioresour. Technol. 2011, 102, 6065-6072. [CrossRef] [PubMed]

5. Rana, S.; Kaur, M. Isolation and screening of cellulase-producing microorganisms from degraded wood. Int. J. Pharm. Biol. Sci. Fundam. 2012, 2, 10-15.

6. Kuhad, R.C.; Gupta, R.; Singh, A. Microbial cellulases and their industrial applications. Enzyme Res. 2011, 2011, 280696. [CrossRef] [PubMed]

7. Sun, Y.; Cheng, J. Hydrolysis of lignocellulosic materials for ethanol production: A review. Bioresour. Technol. 2002, 83, 1-11. [CrossRef]

8. Sukumaran, R.K.; Singhania, R.R.; Pandey, A. Microbial cellulases-Production, applications and challenges. J. Sci. Ind. Res. 2005, 64, 832-844.

9. Cao, L. Carrier-Bound Immobilized Enzymes: Principles, Application and Design; Wiley-VCh: Weinheim, Germany, 2005.

10. Rodrigues, R.C.; Ortiz, C.; Berenguer-Murcia, A.; Torres, R.; Fernandez-Lafuente, R. Modifying enzyme activity and selectivity by immobilization. Chem. Soc. Rev. 2013, 42, 6290-6307. [CrossRef] [PubMed]

11. Tischer, W.; Wedekind, F. Immobilized enzymes: Methods and applications. Top. Curr. Chem. 1999, 200, 96-126.

12. Barbosa, O.; Ortiz, C.; Berenguer-Murcia, A.; Torres, R.; Rodrigues, R.C.; Fernandez-Lafuente, R. Strategies for the one-step immobilization-purification of enzymes as industrial biocatalysts. Biotechnol. Adv. 2015, 33, 435-456. [CrossRef] [PubMed]

13. Brena, B.; González-Pombo, P.; Batista-Viera, F. Immobilization of enzymes and cells. Methods Mol. Biol. 2013, 1051, 5-31.

14. Mateo, C.; Abian, O.; Fernandez-Lorente, G.; Pedroche, J.; Fernandez-Lafuente, R.; Guisan, J.M. Epoxy sepabeads: A novel epoxy support for stabilization of industrial enzymes via very intense multipoint covalent attachment. Biotechnol. Prog. 2002, 18, 629-634. [CrossRef] [PubMed]

15. Hernandez, K.; Fernandez-Lafuente, R. Control of protein immobilization: Coupling immobilization and site-directed mutagenesis to improve biocatalyst or biosensor performance. Enzyme Microb. Technol. 2011, 48, 107-122. [CrossRef] [PubMed]

16. Jędrzak, A.; Rębiś, T.; Klapiszewski, Ł.; Zdarta, J.; Milczarek, G.; Jesionowski, T. Carbon paste electrode based on functional GOx/silica-lignin system to prepare an amperometric glucose biosensor. Sens. Actuators $B$ Chem. 2018, 256, 176-185. [CrossRef]

17. Tao, Q.L.; Li, Y.; Shi, Y.; Liu, R.J.; Zhang, Y.W.; Guo, J. Application of molecular imprinted magnetic $\mathrm{Fe}_{3} \mathrm{O}_{4} @ \mathrm{SiO}_{2}$ nanoparticles for selective immobilization of cellulase. J. Nanosci. Nanotechnol. 2016, 16, 6055-6060. [CrossRef] [PubMed]

18. Velmurugan, R.; Incharoensakdi, A. $\mathrm{MgO}-\mathrm{Fe}_{3} \mathrm{O}_{4}$ linked cellulase enzyme complex improves the hydrolysis of cellulose from Chlorella sp. CYB2. Biochem. Eng. J. 2017, 122, 22-30. [CrossRef]

19. Hong, G.W.; Ramesh, S.; Kim, J.H.; Kim, H.J.; Lee, H.S. Synthesis and properties of cellulose-functionalized POSS-SiO $2 / \mathrm{TiO}_{2}$ hybrid composites. J. Nanosci. Nanotechnol. 2015, 15, 8048-8054. [CrossRef] [PubMed]

20. Hou, J.; Dong, G.; Ye, Y.; Chen, V. Laccase immobilization on titania nanoparticles and titania-functionalized membranes. J. Membr. Sci. 2014, 452, 229-240. [CrossRef]

21. Hou, J.; Dong, G.; Xiao, B.; Malassigne, C.; Chen, V. Preparation of titania based biocatalytic nanoparticles and membranes for $\mathrm{CO}_{2}$ conversion. J. Mater. Chem. A 2015, 3, 3332-3342. [CrossRef]

22. Klapiszewski, Ł.; Zdarta, J.; Antecka, K.; Synoradzki, K.; Siwińska-Stefańska, K.; Moszyński, D.; Jesionowski, T. Magnetite nanoparticles conjugated with lignin: A physicochemical and magnetic study. Appl. Surf. Sci. 2017, 422, 94-103. [CrossRef]

23. Zdarta, J.; Klapiszewski, Ł.; Jędrzak, A.; Nowicki, M.; Moszyński, D.; Jesionowski, T. Lipase B from Candida antarctica immobilized on a silica-lignin matrix as a stable and reusable biocatalytic system. Catalysts 2017, 7, 14. [CrossRef]

24. Hanefeld, U.; Gardossi, L.; Magner, E. Understanding enzyme immobilization. Chem. Soc. Rev. 2009, 38, 453-468. [CrossRef] [PubMed]

25. Magri, M.L.; Miranda, M.V.; Cascone, O. Immobilization of soybean seed coat peroxidase on polyaniline: Synthesis optimization and catalytic properties. Biocatal. Biotransform. 2005, 22, 339-346. [CrossRef] 
26. Eslamipour, F.; Hejazi, P. Evaluating effective factors on activity and loading of immobilized $\alpha$-amylase onto magnetic nanoparticles using response surface desirability approach. RSC Adv. 2016, 6, 20187-20197. [CrossRef]

27. Hou, J.; Dong, G.; Ye, Y.; Chen, V. Enzymatic degradation of bisphenol-A with immobilized laccase on $\mathrm{TiO}_{2}$ sol-gel coated PVDF membrane. J. Membr. Sci. 2014, 469, 19-30. [CrossRef]

28. Zhang, D.H.; Zhang, Y.F.; Zhi, G.Y.; Xie, Y.L. Effect of hydrophobic/hydrophilic characteristics of magnetic microspheres on the immobilization of BSA. Colloids Surf. B 2011, 82, 302-306. [CrossRef] [PubMed]

29. Straksys, A.; Kochane, T.; Budriene, S. Catalytic properties of maltogenic $\alpha$-amylase from Bacillus stearothermophilus immobilized onto poly(urethane urea) microparticles. Food Chem. 2016, 211, $294-299$. [CrossRef] [PubMed]

30. Hirsh, S.L.; Bilek, M.M.M.; Nosworthy, N.J.; Kondyurin, A.; dos Remedios, C.G.; McKenzie, D.R. A comparison of covalent immobilization and physical adsorption of a cellulase enzyme mixture. Langmuir 2010, 26, 14380-14388. [CrossRef] [PubMed]

31. Mubarak, N.N.; Wong, J.R.; Tan, K.W.; Sahu, J.N.; Abdullah, E.C.; Jayakumar, N.S.; Ganesan, P. Immobilization of cellulase enzyme on functionalized multiwall carbon nanotubes. J. Mol. Catal. B Enzym. 2014, 107, 124-131. [CrossRef]

32. Khorshidi, K.J.; Lenjannezhadian, H.; Jamalan, M.; Zeinali, M. Preparation and characterization of nanomagnetic cross-linked cellulase aggregates for cellulose bioconversion. J. Chem. Technol. Biotechnol. 2016, 91, 539-546. [CrossRef]

33. Bohara, R.A.; Thorat, N.D.; Pawar, S.H. Immobilization of cellulase on functionalized cobalt ferrite nanoparticles. Korean J. Chem. Eng. 2016, 33, 216-222. [CrossRef]

34. Abraham, R.E.; Verma, M.L.; Barrow, C.J.; Puri, M. Suitability of magnetic nanoparticle immobilised cellulases in enhancing enzymatic saccharification of pretreated hemp biomass. Biotechnol. Biofuels 2014, 7, 1-12. [CrossRef] [PubMed]

35. Zhang, W.; Qiu, J.; Feng, H.; Zang, L.; Sakai, E. Increase in stability of cellulase immobilized on functionalized magnetic nanospheres. J. Magn. Magn. Mater. 2015, 375, 117-123. [CrossRef]

36. Sharma, S.; Kaur, P.; Jain, A.; Rajeswari, M.R.; Gupta, M.N. A smart bioconjugate of chymotrypsin. Biomacromolecules 2003, 4, 330-336. [CrossRef] [PubMed]

37. Li, Y.; Wang, X.Y.; Zhang, R.Z.; Zhang, X.Y.; Liu, W.; Xu, X.M.; Zhang, Y.W. Molecular imprinting and immobilization of cellulase onto magnetic $\mathrm{Fe}_{3} \mathrm{O}_{4} @ \mathrm{SiO}_{2}$ nanoparticles. J. Nanosci. Nanotechnol. 2014, 14, 2931-2936. [CrossRef] [PubMed]

38. Sanchez-Ramirez, J.; Martinez-Hernandez, J.L.; Segura-Ceniceros, P.; Lopez, G.; Saade, H.; Medina-Morales, M.A.; Ramos-Gonzalez, R.; Aguilar, C.N.; Ilyina, A. Cellulases immobilization on chitosan-coated magnetic nanoparticles: Application for Agave atrovirens lignocellulosic biomass hydrolysis. Bioprocess. Biosyst. Eng. 2017, 40, 9-22. [CrossRef] [PubMed]

39. Zhang, D.; Hegab, H.E.; Lvov, Y.; Snow, L.D.; Palmer, J. Immobilization of cellulase on a silica gel substrate modified using a 3-APTES self-assembled monolayer. SpringerPlus 2016, 5, 1-20. [CrossRef] [PubMed]

40. Dutta, N.; Biswas, S.; Saha, M.K. Biophysical characterization and activity analysis of nano-magnesium supplemented cellulase obtained from a psychrobacterium following graphene oxide immobilization. Enzym. Microb. Technol. 2016, 95, 248-258. [CrossRef] [PubMed]

41. Swarnalatha, V.; Esther, R.A.; Dhamodharan, R. Immobilization of $\alpha$-amylase on gum acacia stabilized magnetite nanoparticles, an easily recoverable and reusable support. J. Mol. Catal. B Enzym. 2013, 96, 6-13. [CrossRef]

42. Lima, J.S.; Araujo, P.H.H.; Sayer, C.; Viegas, A.C.; de Oliveira, D. Cellulase immobilization on magnetic nanoparticles encapsulated in polymer nanospheres. Bioprocess. Biosyst. Eng. 2017, 40, 511-518. [CrossRef] [PubMed]

43. Bayramoglu, S.G.; Kiralp, S.; Yilmaz, M.; Toppare, L.; Arica, M.Y. Covalent immobilization of chloroperoxidase onto magnetic beads: Catalytic properties and stability. Biochem. Eng. J. 2008, 38, 180-188. [CrossRef]

44. Senyay-Oncel, D.; Yesil-Celiktas, O. Characterization, immobilization, and activity enhancement of cellulase treated with supercritical $\mathrm{CO}_{2}$. Cellulose 2015, 22, 3619-3631. [CrossRef] 
45. Klapiszewski, Ł.; Siwińska-Stefańska, K.; Kołodyńska, D. Preparation and characterization of novel $\mathrm{TiO}_{2}$ /lignin and $\mathrm{TiO}_{2}-\mathrm{SiO}_{2}$ /lignin hybrids and their use as functional biosorbents for $\mathrm{Pb}(\mathrm{II})$. Chem. Eng. J. 2017, 314, 169-171. [CrossRef]

46. Klapiszewski, Ł.; Siwińska-Stefańska, K.; Kołodyńska, D. Development of lignin based multifunctional hybrid materials for $\mathrm{Cu}(\mathrm{II})$ and Cd(II) removal from the aqueous system. Chem. Eng. J. 2017, 330, 518-530. [CrossRef]

47. Bradford, M.M. A rapid and sensitive method for the quantitation of microgram quantities of protein utilizing the principle of protein-dye binding. Anal. Biochem. 1976, 72, 248-254. [CrossRef]

48. Miller, G.L. Use of dinitrosalicylic acid reagent for determination of reducing sugar. Anal. Chem. 1959, 31, 426-428. [CrossRef]

(C) 2017 by the authors. Licensee MDPI, Basel, Switzerland. This article is an open access article distributed under the terms and conditions of the Creative Commons Attribution (CC BY) license (http:/ / creativecommons.org/licenses/by/4.0/). 